(C) К.К. Карпенко, 2020

УДК 616.14-089

\title{
Діагностичні можливості у виборі хірургічної тактики лікування посттромботичної хвороби
}

\author{
К.К. Карпенко
}

Національний військово-медичний центр “Головний військовий клінічний госпіталь”, Київ

\section{Реферат}

У статті розглядаються пробеми у діагностиці стенотично-оклюзивних уражень глибоких вен тазу та нижньої порожнистої вени при посттромботичній хворобі. На даний момент діагостика даної патології має різноплановий характер, хоча стратегія хірургічного лікування та вибір тактики у багатьох випадках залежить також від повноти і специфічності отриманої діагностичної інформації. Різноманітні інструментальні методики мають неоднакові рівні точності та повноти отримуваної інформації. Для визначення оптимальної схеми діагностики на практичному досвіді були застосовані та порівняні між собою найбільш доступні та вживані методи інструментальної діагностики у відповідності з Рекомендаціями американського коледжу радіології, а також оцінено їх значимість у плануванні майбутніх хірургічних чи ендоваскулярних втручань, розглянуті переваги та недоліки кожного з методів.

Ключові слова: посттромботична хвороба, флебографія, цифрова субтракційна флебографія, мультиспіральна комп'ютерна флебографія, УЗДГ вен, алгоритм діагностики, венозна реконструкція.

\author{
Diagnostic possibilities in the choice o surgical tactics for the treatment of post-thrombotic disease \\ K.K. Karpenko \\ National Military Medical Center "Main Military Clinical Hospital", Kyiv
}

\section{Abstract}

In the article discussed problems in the diagnosis of stenotic-occlusal lesion sof the deep veins of the pelvis and inferior vena cava with post-thrombotic disease. At the moment, the diagnos is of this pathology is diverse, although the strategy of surgical treatment and the choice of tactics in many cases depends on the completeness and specificity of the received diagnostic in formation. Different instrumental techniques have unequal levels of accuracy and completeness of the information received. To determine the optimal diagnostics chemein practical experience, the most affordable and applicable instrumental diagnostic methods were applied and compared among them selves inaccordance with the Recommendations of the American College of Radiology, their significance in planning future surgical or endovascular interventions was evaluated, and the advantages and disadvantages of each method were examined.

Key words: post-thrombotic disease, phlebography, digital subtraction phlebography, multi-helical computer phlebography, ultrasound vein diagnostics, diagnostic algorithm, venous reconstruction.

Вступ. Посттромботична хвороба - це хронічна венозна патологія, пов'язана з перенесеним гострим тромбозом глибоких вен (ТГВ), у літературних джерелах країн Північної Америки та країн Європейського Союзу трапляється назва "посттромбофлебітичний синдром". Посттромботична хвороба (ПТХ) - патологія, обумовлена подальшими стено-оклюзуючими патоморфологічними i патофізіологічними процесами у венозній системі, які об'єднуються в окрему нозологічну форму 3 типовими зовнішніми проявами і характерними порушеннями регіонарної та центральної гемодинаміки, органічним ураженням глибоких вен внаслідок перенесеного тромбозу. У 30-50\% пацієнтів iз тромбозом глибоких вен протягом п'яти років розвивається посттромботична хвороба. Симтоми хвороби варіюються від легкого дискомфорту та важкості в ногах до інвалідизації пацієнта [1]. Відповідно до Рекомендацій Американського Кардіологічного Товариства (The American Heart Association Scientific Statement) [2] щодо хірургічного та ендоваскулярного лікування ПТХ - існують рівні доказовості класу IIb; рівень доказів C, які розглядають такі втручання: комбінована оперативна та кінцева дезоблітерація вен, сегментарне відновлення клапанів вен або венозна транспозиція [3], та класу IIb; рівень доказів В - балонна ангіопластика та венозне стентування [4]. Вибір стратегії медикаментозного лікування та вибір хірургічної тактики у багатьох випадках залежить також від повноти і специфічності отриманої діагностичної інформації.

Актуальність. На даний час “золоті стандарти” діагностики ПТХ відсутні, що також безпосередньо впливає на вибір стратегії лікування та оптимальної методики лікування даної хвороби [2, 5]. Питання щодо оптимального алгоритму діагностики та алгоритму лікування ПТХ мають різноплановий характер, але при резистентності до консервативної терапії перевага віддається до хірургічного лікування [5]. У випадку локалізації посттромботичного процесу до рівня Пупартової зв'язки, діагностичних складностей, як правило, не спостерігається - анамнез та клінічна картина доповнюється даними УЗДГ вен нижньої кінцівки, проте у випадку локалізації патологічного процесу в ділянках здухвинних вен або нижньої порожнистої вени діагностика ускладнюється. Як відомо, згідно з анатомічною локалізацією, ураження ілеокавального сегменту спостерігається у $36,48 \%$ 
пацієнтів [6]. Хірургічні або ендоваскулярні втручання для лікування пацієнтів із ПТХ мають добрий потенціал для зменшення посттромботичної захворюваності, пов'язаної з глибокою венозною обструкцією [2,7,9]. Алгоритм діагностичної інструментальної тактики визначено в “Критеріях вибору методу інструментальної діагностики вен Американського Радіологічного Коледжу", де активно проводяться мініінвазивні хірургічні втручання на магістральних венах тазу та нижній порожнистй вені, проте в Україні це питання неоднозначне, хоча вибір хірургічної тактики, безумовно, дуже залежить від якісної діагностики. Масштабні багатоцентрові рандомізовані дослідження за цією проблемою не проводились, оскільки досвід цих процедур обмежений, і тільки пацієнти 3 найбільш тяжкими формами хвороби лікуються хірургічно. Крім того, частина опублікованого досвіду передує розробці об'єктивних стандартів звітності для оцінки пацієнтів, які проходять хірургічне лікування хронічного венозного захворювання [2, 8].
Мета дослідження: визначення оптимального методу інструментальної діагностики для хірургічної тактики лікування посттромботичної хвороби.

Матеріали та методи. Упродовж 2019 року на базі НВМКЦ "ГВКГ" та ОКЛ м. Києва було обстежено 38 пацієнтів 3 верифікованим діагнозом "Посттромботична хвороба" 3 анатомічною локалізацією у ілеокавальному сегменті. Як алгоритм діагностики вен були використані Критерії вибору методу інструментальної діагностики вен Американського Радіологічного Коледжу та оцінено їх практичне використання для якісної інформативної діагностики здухвинних вен (3В) та нижньої порожнистої вен (НПВ) для вибору подальшої хірургічної тактики. Перед кожним методом ставили задачі 3 оцінки стану глибоких вен тазу та нижньої порожнистої вени - діаметр (мм), протяжність оклюзії / стенозу, та характеристика конфлюенсу ЗВ у НПВ, наявність колатерального кровообігу, шляхи відтоку).

Таблиця 1

Критерії вибору методу інструментальної діагностики вен Американського радіологічного коледжу

\begin{tabular}{|l|c|}
\hline \multicolumn{1}{|c|}{ Метод дослідження } & Бал \\
\hline УЗДГ із компресією & 9 \\
\hline Інвазивна флебографія тазу & 6 \\
\hline МРТ-флебографія & 6 \\
\hline КТ із контрастуванням тазу & 6 \\
\hline Інвазивна флебографія судин & 5 \\
\hline КТ-флебографія & 6 \\
\hline Радіоізотопна флебографія & 3 \\
\hline Рентгенографія нижніх кінцівок & 2 \\
\hline УЗД & 1 \\
\hline
\end{tabular}

Враховуючи доступність та інформативність методів, дослідження, що отримували менше 5 балів не використовувались.

Результати досліджень та їх обговорення. Ультразвукове дуплексне сканування вен тазу та органів черевної порожнини проводилось ультразвуковими скануючими приладами експертного рівня Ultima PA Expert, Radmir, Україна, та Appleo, Toshiba, Японія.

Дослідження вен нижніх кінцівок проводилось натщесерце в горизонтальному положенні хворого. Для дослідження нижньої порожнистої і клубових вен застосовували конвексний або секторний датчик 3 випромінюваною частотою 3,5 МГц. Застосовувався В режим, спектральний (імпульсний) доплерівський режим, а також режими кольорового доплерівського картування (КДК) кровотоку на підставі швидкості і енергії відбитого сигналу. Дуплексне сканування надає можливість багаторазового повторного огляду венозної системи для спостереження в динаміці процесу формування, наростання, лізису і організації тромбу, а також обтурації і реканалізації судини. Основною ознакою тромбозу є виявлення ехопозивних тромботичних мас у просвіті судини. Ехогенність зростає в міру збільшення "віку" тромбу. При перенесених тромботичних процесах у венозній системі стулки клапанів не диференціюються, зникає властива здоровим венам передавальна артеріальна пульсація. Діаметр ураженої вени може збільшитися у 22,5 разу, в порівнянні 3 колатеральною судиною, як відомо, тромбована вена не реагує на компресію датчиком, проте провести компресію здухвинних вен та нижньої порожнистої вени у низці випадків неможливо. Дослідження вен у режимі колірного доплерівського картування кровотоку дозволяє диференціювати "свіжі тромби", ехогенність яких істотно не відрізняється від просвіту вени в В режимі. При КДК тромботичні маси виглядають як дефекти "контрастування". На 3-4-ий день виникає ущільнення і потовщення стінок вен за рахунок запалення. Запалення навколишніх 
тканин створює "розмитість" сигналу від паравазальних структур.

За даними УЗДГ досліджень оклюзивні або стенозуючі ураження виявили у 35 з 38 пацієнтів (92,1\%), проте, незважаючи на високу чутливість, метод не може забезпечити точною інформацією щодо діаметра ЗВ та НПВ, точними даними початку та закінчення ураження, відповідно - протяжності ураження, неможливість точного визначення рівня конфлюенса здухвинних вен у нижню порожнисту вену.

Важливим фактором $є$ те, що протипокази до УЗДГ відсутні.

Мультиспіральна комп'ютерна флебографія (3 контрастуваням). Дослідження проводилося на 64-х зрізовому мультиспіральному комп’ютерному томографі “Optima”, компанії General Electric, виробництва США, з інстальованим пакетом програм для обробки зображень GE Advantage Workstation.

Для дослідження катетеризували ліктьову вену, використовуючи внутрішньовенний катетер. В інфузійний шприц набирається 100 мл неіонної контрастної речовини Ультравіст $320 \mathrm{mg}$; за допомогою інфузійної магістралі шприц з'єднується 3 внутрішньовенним катетером і включається режим інфузії. Дослідження проводили у судинному протоколі Phlebography (ASIR 50). Після попереднього сканування в режимі SmartPrepRx задається ділянка сканування (гомілка, стегно, уся нижня кінцівка, обидві нижні кінцівки). Основне сканування (перший ступінь) запускається в ручному режимі із затримкою старту в 40-60 секунд, після закінчення введення контрастного препарату. Реконструкцію тривимірного зображення вен проводили за допомогою автоматичних протоколів обробки даних, закладених у комп'ютерному томографі і доступних для комерційного використання. Також проводилося і відстрочене двоступеневе двонаправлене сканування при достатньому і рів- номірному заповненні венозного русла нижньої кінцівки рентгеноконтрастною сумішшю, чим покращується якість 3d-реконструкції зображення вен після сканування і полегшується правильна інтерпретація отриманих даних.

Важливим моментом при проведенні протоколу дослідження $є$ розрахунок оптимального часу для початку сканування, який залежить від особливостей гемодинаміки у кожного пацієнта, цей параметр є індивідуальним, та визначається МСКТ лаборантом у кожному окремому випадку. За допомогою МСКТ 3 контрастуванням визначили стан глибоких вен тазу, нижньої порожнистої вени - діаметр, протяжність оклюзії / стенозу, наявність колатерального кровообігу та визначили шляхи венозного відтоку. Також забезпечується можливість виявлення наслідків перенесеного тромбофлебіту у вигляді часткової реканалізації судини або повну облітерацію просвіту вени, що перетворюється в сполучнотканинний тяж. Цікавою особливістю $€$ те, що навіть всередині тяжа можна виявити просвіт приблизно до 1 мм (важливо при плануванні ендоваскулярних втручань). Також метод дозволяє виявити ознаки обтурації венозного просвіту (частіше після рецидивів гострого тромбофлебіту), що призводить до формування флеболітів унаслідок петрифікації тромбу у варикозно-розширених венах нижніх кінцівок, венах тазового сплетіння, широких зв'язок матки, селезінки, іноді печінки. За допомогою МСКТ флебографії виявляються шляхи відтоку через колатералі тазу, гонадні вени та люмбальні вени. Методика була викориснана у 28 з 38 (73,68\%) пацієнтів, олкюзивні або стенотичні ураження були виявлені у $28(100 \%)$ пацієнтів, 4 пацієнти $(14,29 \%)$ повідомили про відчуття жару під час введення контрастної речовини, 1 (3,57\%) випадок гіпотонії, що було куповано медичними засобами.

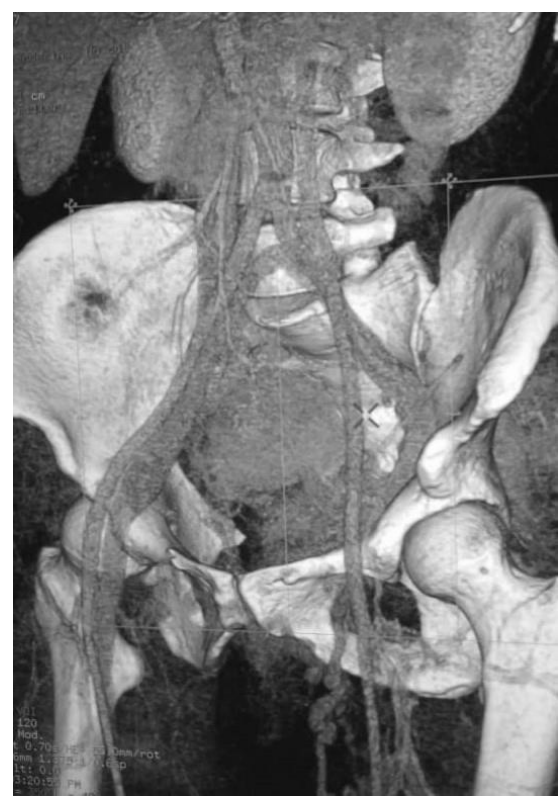

Рис. 1. МСКТ із контрастуванням. Оклюзія глибокої вени лівої н.к. на рівні гирла, оварікоцеле, відтік крові від нижньої кінцівки по лівій яєчниковій, нирковій вені та варикозних колатеральних пубікальних венах. 
МСКТ флебографія: виконання даної діагностики дуже подібне до МСКТ із контрастуванням, особливість цього виду діагностики полягає у тому, що катетеризується безпосередньо тильна вена стопи, або підколінна вена (під контролем УЗД), а контрастну речовину подають в об'ємі 100 мл, швидкість 4 мл / сек. За рахунок можливості забезпечення постійної високої внутрішньовенної концентрації йодвмісної речовини під час дослідження, якість зображення при 3D реконструкції значно підвищується, а також посилюється якість візуалізації колатеральних судин та шляхів відтоку при оклюзивних станах і значних стенозах.

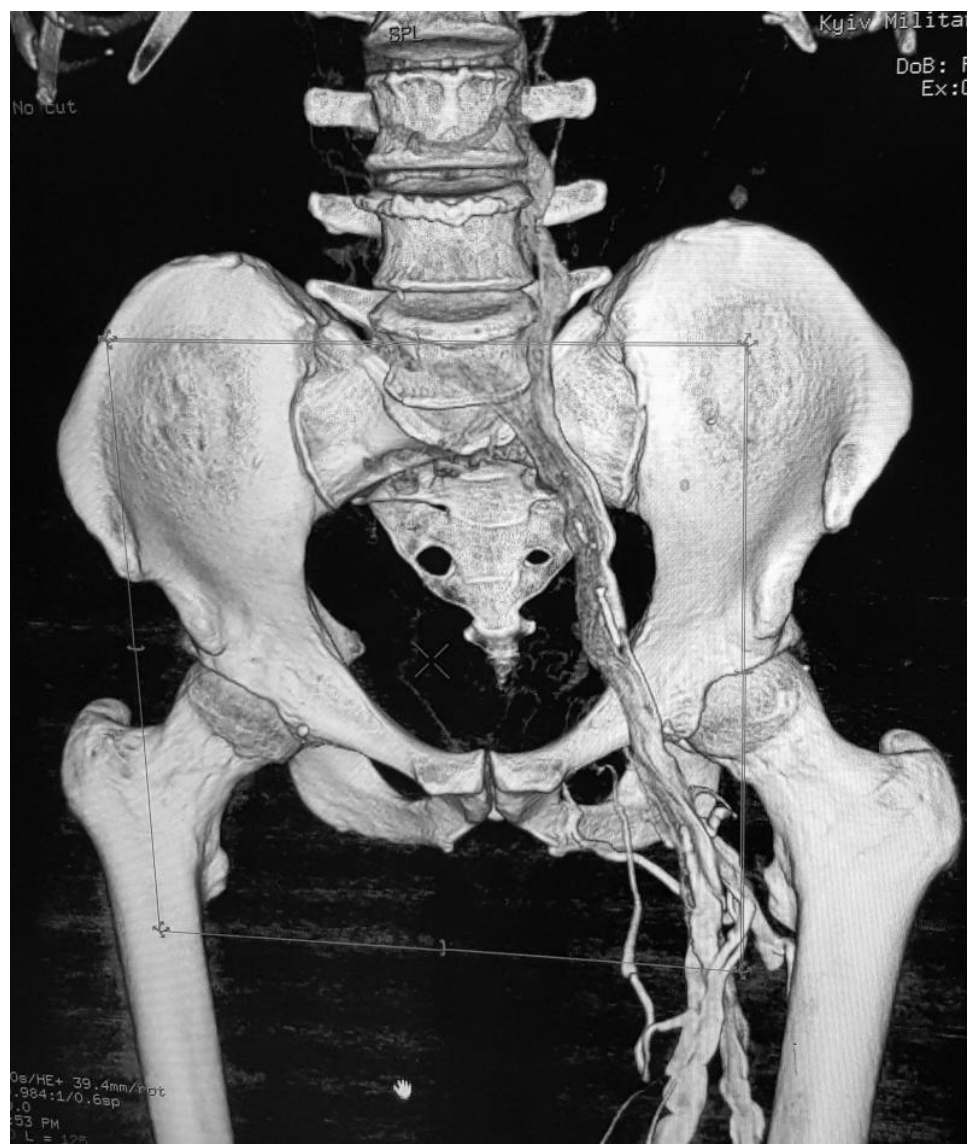

Рис. 2. МСКТ флебографія. Стеноз 95\% лівої зовнішньої здухвинної вени. Оклюзія нижньої порожнистої вени до рівня ниркових артерій. Відтік крові по люмбальних колатералях.

Недоліками методики можна вважати розмитий рівень конфлюенса здухвинних вен у НПВ. Методика була викориснана у 5 (13,6\% від загальної кількості) пацієнтів, олкюзивні або стенотичні ураження були виявлені у 5 (100\%), проблемна пункція вени нижньої кінцівки у 2 пацієнтів (40\%), 1 пацієнт (20\%) повідомив про болісність у нижній кінцівці під час введення контрастної речовини.

Пряма цифрова субтракційна флебографія (ЦСФ). Дослідження проводилось 3 використанням стаціонарної рентген-ангіографічної системи Innona2100, General Electric, Франція, Alphenix Core+, Canon Medical, Японія з використанням програмного забезпечення QCA, QVA, DCA, DCA roadmap. Флебографія не використовується як першочерговий метод вибору інструментальної діагностики; оскільки це доволі болісна та дороговартісна процедура, яка забирає багато часу, дає пацієнту досить високу дозу опромінення і може спричинити ускладнення. Для виконання дослідження уражену кінцівку бинтують еластичним бинтом вище коліна, потім пунктують будь-яку вену стопи досліджуваної кінцівки голкою 21-23G калібру. Для контрастування використовують до 100 мл контрастної речовини “Візипак 320” або іншої ізоосмолярної йодвмісної контрастної речовини та вводять іiі внутрішньовенно зі швидкістю 3-5 мл / сек. Під час введення контрасту під флюороскопічним контролем проводили графічну зйомку в режимі цифрової субтракції у декількох проекціях. Як правило, одномоментно проводились дослідження вен всієї кінцівки, вен тазу і НПВ до рівня ниркових вен, проте у випадку локального звуження або оклюзії здухвинних вен, проводилась тільки флебографія тазу. Ця методика забезпечує якісну деталізацію, особливо у випадку подальшого планування реконструкційних втручань у пацієнтів з ПТНХ. У деяких випадках роблять місцеву анестезію в місці введення інтродьюсера. Інколи може знадобитися невеликий розріз, щоб забезпечити вільну постановку інтродьюсера, не пошкоджуючи навколишні тканини та стінку вени. 
Вводять катетер і повільно вводять контрастний розчин під флюороскопічним контролем, ділянку інтересу знімають графічно, мінімум у двох проекціях. Методика була використана у 5 з 38 (13,6\%) пацієнтів, оклюзивні або стенотичні ураження були виявлені у 5 (100\%), 1 пацієнт (20\%) повідомив про болісність у нижній кінцівці під час введення контрастної речовини та відчуття жару в нозі, яке може поширюватися по тілу. 1 (20\%) пацієнт повідомив про нудоту. У випадку оклюзивних змін у магістра- льній вені не вдається визначити протяжність ураження, оскільки колатеральні судини можуть скидати венозну кров на достатньо далекій відстані, відповідно не можна чітко визначити рівень конфлюенсу ЗВ та діаметр НПВ. Недоліком ЦСФ є важкість визначення справжнього діаметра ураженої судини - візуалізується тільки ії внутрішній просвіт. Важлива відмінність між методикою прямої ЦСА від МСКТ полягає у можливості візуалізації внутрішньолюмінальних деталей.

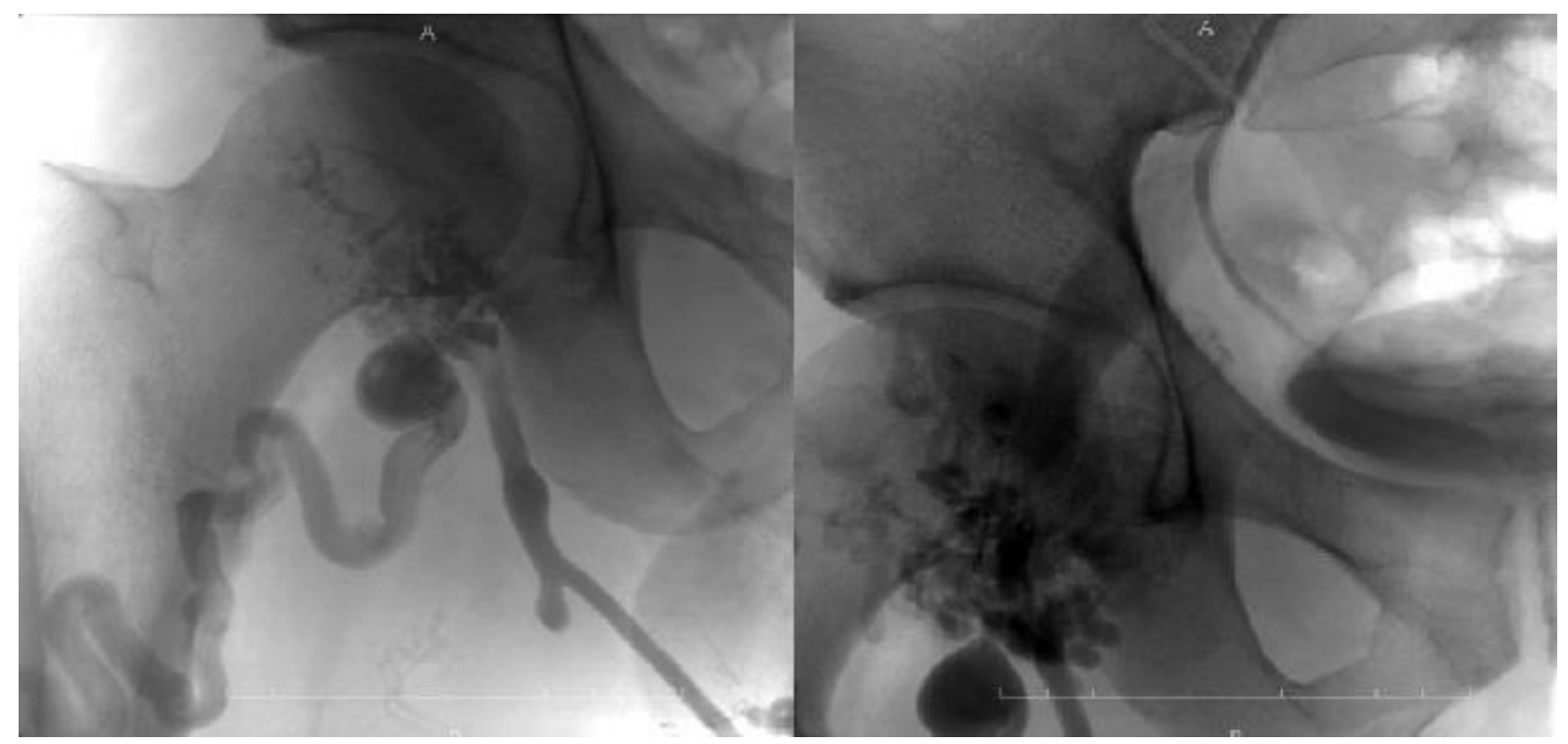

Рис. 3. ЦСФ правої н.к. Постін’єкційний стеноз гирла глибокої вени стегна 90\%, венозна аневризма та варикозні зміни поверхневої латеральної вени стегна.

ЦСФ може спричинити ускладнення: флебіт, пошкодження тканин та формування тромбозу глибоких вен кінцівки. Рідкісним побічним ефектом є алергічна реакція на контраст. Зазвичай це відбувається протягом 30 хвилин після введення i вимагає медичної допомоги. У більшості випадків пацієнт може відновити звичайну діяльність від 1-ї до 24-х годин.

Важливо зазначити, що за даними літератури, магнітно-резонансна флебографія забезпечує чудові результати візуалізації та точність даних, не використовуючи випромінювання чи контраст, але дана методика при дослідженні тазових вен та НПВ в Україні не доступна.

Висновки. “Золотого стандарту” у діагностиці глибоких вен тазу та НПВ на даний час немає, для отримання повної інформації для визначеня подальшої хірургічної тактики при лікуванні посттромботичної хвороби у більшості випадків потрібна комбінація методів. Для ендоваскулярних реконструктивних методів найбільш повну інформацію надає МСКТ із контрастуванням та цифрова субтракційна флебографія, для хірургічних реконструкцій найбільш підходящими, на нашу думку, $є$ комбінація УЗДГ та МСКТ флебографія. Інвазивні методи дослідження мають використовуватися лише в обмежених випадках і тільки у випадку планування майбутнього оперативного втручання. Поява магнітнорезонанстої флебографії в Україні могла б значно підвищити якість діагностики пацієнтів із посттромботичною хворобою.

Інформація про конфлікт інтересів. Конфлікту інтересів немає.

Інформація про фінансування. Автор гарантує, що він не отримував жодних винагород у будь-якій формі, здатних вплинути на результати роботи.

Особистий внесок кожного автора у виконання роботи:

Карпенко К.К. - ідея, мета, збір матеріалу дослідження, аналіз отриманих результатів, підготовка тексту статті.

\section{Список використаної літератури}

1. The long-term clinical course of a cute deep venous thrombosis / [P. Prandoni, A. Lensing, A. Cogota ін.]. // 1996. №125. C. 1-7. 
2. The postthrombotic syndrome: evidence-based prevention, diagnosis, and treatment strategies: a scientific statement from theAmerican Heart Association. / [S. Kahn, A. Comerota, M. Cushmanta ін.]. // Circulation. 2014. - №130. - C. 1636-1661.

3. Reconstructive operations on the venous system: late results with a critical assessment of the functional and vascular morphological criteria / [S. Hutschenreiter, J. Vollmar, H. Loeprechtтa ін.] // Chirurg. 1979. №50. C. 555-563.

4. Stenting of the venous outflow inc hroni cvenous disease: long-term stent-related outcome, clinical, and hemodynamic result / P.Neglen, K. Hollis, J. Olivier, S. Raju. // J VascSur. 2007. №46. C. 979-990.

5. Post-thrombotic syndrome in patients treated with rivaroxabanorenoxaparin/vitamin $\mathrm{K}$ antagonists for a cute deep-vein thrombosis. A post-hocanalysis. / [Y. Cheung, S. Middeldorp, M. Prinsta iH.] // Thromb Haemost. 2016. №116. С. 733.

6. Комплексне лікування посттромботичної хвороби н/к.Конгрес асоціації судинних хірургів, флебологів та ангіологів України, присвячений 80-річчю з дня народження проф. I.І.Сухарева - засновника судинної хірургії та флебології України. м. Київ, 11-12 квітня 2019 року. Черняк В.А., Мішалов В.Г., Селюк В.М., Карпенко К.К.

7. Nayak L. Posthrombotic syndrome: feasibility of a strategy of imaging-guided endovascular intervention / L. Nayak, C. Hildebolt, S. Vedantham. // J VascIntervRadiol. 2012. №23. C. 1165-1173.

8. The economic burd enofincident venous thromboembolism in the United States: A review of estimated at tribut able health care costs / [S. Grosse, R. Nelson, K. Nyarkota ін.]. // ThrombRes. 2016. №3. C. 137.

9. Vein wall remodeling in patients with a cute deep veinthrombosis and chronic postthrombotic changes / [A. Chandrashekar, J. Garry, A. Gasparista iн.]. // J Thromb Haemost. 2017. №15. C. 1989.

Стаття надійшла до редакції: 28.02.2020 р. 